\title{
Colletotrichum gloeosporioides causing leaf anthracnose on Oxalis corniculata in Brazil
}

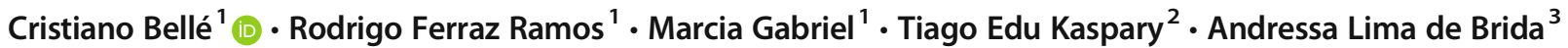

Received: 9 July 2019 / Accepted: 12 November 2019 / Published online: 21 November 2019

(C) Australasian Plant Pathology Society Inc. 2019

\begin{abstract}
Anthracnose leaf spot of creeping woodsorrel (Oxalis corniculata), caused by Colletotrichum gloeosporioides, is reported for the first time in Brazil. The identity of the etiological agent was confirmed by a combination of morphological and molecular information. Koch's postulates were fulfilled with a selected isolate of this fungus obtained at Santa Maria, state of Rio Grande do Sul, Brazil.
\end{abstract}

Keywords Fungal pathogen $\cdot$ Ocurrence $\cdot$ Creeping woodsorrel $\cdot$ Leaf spots

Creeping woodsorrel (Oxalis corniculata) is a cosmopolitan species found in tropical and temperate areas, occurring as a weed in fields of beans, coffee, corn, potato and rice, where it can cause significant losses in yield. It is also present in grasslands, greenhouses, nurseries, and garden areas causing losses of plants (Hodi et al. 2014; CABI 2019). In addition, it may be an alternative host of pests and pathogens of crops (Guerra et al. 2016; Bellé et al. 2016).

Colletotrichum includes a large number of plant pathogens of major importance, causing diseases and affecting production of horticultural crops, such as avocado, banana, citrus, mango, strawberry, but can cause devastating disease with as well as crops such as coffee, maize, sorghum and sugarcane (Cannon et al. 2012). Anthracnose symptoms include limited, often sunken, necrotic lesions on leaves, stems, flowers and

Cristiano Bellé

crbelle@gmail.com

1 Centro de Ciências Rurais, Universidade Federal de Santa Maria, Santa Maria, Rio Grande do Sul, Brazil

2 Instituto Nacional de Investigación Agropecuaria - INIA La Estanzuela, Colonia, Uruguay

3 Departamento de Ecologia, Zoologia e Genética, Universidade Federal de Pelotas, Pelotas, Rio Grande do Sul, Brazil fruit, as well as crown and stem rots, and seedling blight (Agrios 2005; Cannon et al. 2012).

Creeping woodsorrel leaf with anthracnose symptoms, circular to oval brown spots (Fig. 1), were collected in Santa Maria (GPS coordinates: $29^{\circ} 42^{\prime} 56^{\prime \prime} \mathrm{S}$; 53 $3^{\circ} 42^{\prime}$ $21^{\prime \prime}$ ), Rio Grande do Sul state, Brazil, in September 2018. Leaf lesion samples were surface sterilized $(5 \times$ $3 \mathrm{~mm}$ ) and placed on potato dextrose agar (PDA) at $25{ }^{\circ} \mathrm{C}$ with a 12-h photoperiod for 5 days. Colonies on PDA are circular, white to gray, with white margins and aerial hyphae, and the reverse of the colonies were gray to brown. Acervuli were dark brown without the presence of setae. Conidia were one-celled, cylindrical, hyaline, rounded at both ends, measuring $(n=100) 15.4$ (14.4$17.5) \pm 1.5 \times 4.3(3.5-5.0) \pm 0.5 \mu \mathrm{m}$ were observed similar to the description of Colletotrichum sp. (Weir et al. 2012).

Genomic DNA was extracted from a 7-day-old colony grown on PDA (isolate LPS031). Extraction was performed with a Wizard ${ }^{\circledR}$ Genomic DNA purification kit (Promega, USA) according to the manufacturer's instructions. The actin (ACT), calmodulin (CAL), chitin synthase (CHS-1), glyceraldehyde-3-phosphate dehydrogenase (GAPDH) and $\beta$-tubulin (TUB2) genes were amplified and sequenced (Weir et al. 2012). A Maximum Likelihood tree was constructed using representative isolates of Colletotrichum (Weir et al. 2012) to determine the phylogenetic relationship. Each gene sequence was aligned using CLUSTAL X (Thompson et al. 1997) for 
Fig. 1 (A-C) Symptoms of leaf anthracnose caused by Colletotrichum gloeosporioides on Oxalis corniculata

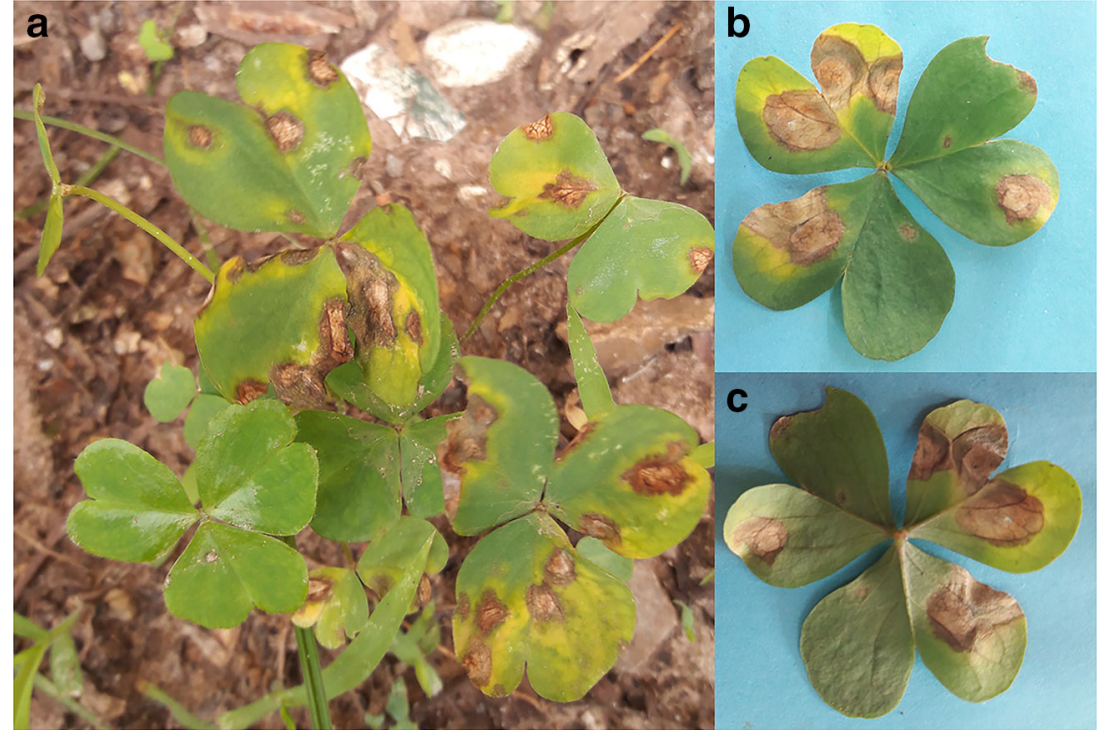

a combined analysis using MEGA v7.0 (Kumar et al. 2016). The maximum likelihood analysis with 1000 bootstrap replicates was performed was performed in MEGA v7.0 (Kumar et al. 2016) using the Jukes-Cantor model (Jukes and Cantor 1969).

Sequences of the obtained DNA regions were submitted to GenBank (Accession Nos. ACT: MK639182, CAL: MK639180, CHS-1: MK639183, GAPDH: MK639184 and TUB2: MK639181,). MegaBLAST searches showed $99 \%$ to $100 \%$ identity with sequences of Colletotrichum gloeosporioides ex-type strain CBS 112999 (ACT: JQ005500, CAL: JQ005673, CHS-1: JQ005326, GAPDH: JQ005239 and TUB2: JQ005587). The phylogram constructed using combined datasets showed that isolates clustered into distinct clades with high bootstrap replicates; the isolate from this study clustered with C. gloeosporioides with $99 \%$ bootstrap (Fig. 2). Pure cultures were obtained and deposited in the culture collection of the Universidade Federal de Pelotas under the accession number LPS031.

To confirm Koch's postulates, six plants of $O$. corniculata were inoculated with a spore suspension $\left(10^{5}\right.$ conidia/ml) of $C$. gloeosporioides from a 7 -day-old culture. The conidial suspension was sprayed with an atomizer on all leaf surfaces of $O$. corniculata plants 20-days-old. After inoculation, the plants were covered with plastic bags to maintain high relative humidity, maintained at $25^{\circ} \mathrm{C}$ with a 12 -h photoperiod and mon- itored daily for symptom development. Six plants inoculated with sterile water served as controls. Four days after inoculation, leaves displayed symptoms similar to those observed in the field, while controls remained symptomless. The pathogen was consistently re-isolated from the infected leaves and had the same morphological and molecular traits as the initial isolates.

Our findings highlight the relevance of O. corniculata, which may serve as a reservoir for Colletotrichum gloeosporioides. Colletotrichum gloeosporioides has been reported as a fungus causing various diseases mainly leaf anthracnose on a wide range of plant hosts in Brazil. It was, for example, reported as the cause of leaf spot of Capsicum sp., Carica papaya, Citrullus lanatus, Citrus sp., Cucumis melo, Cucurbita pepo, Fragaria $\times$ ananassa, Glycine max, Gossypium sp., Malus domestica, Mangifera indica, Manihot esculenta, Olea europaea, Prunus persica, Solanum lycopersicum and Vitis sp. (ANDEF 2019; Farr and Rossman 2019). From the literature consulted this is the first report in the presence of $C$. gloeosporioides affecting $O$. corniculata plants in Brazil. Therefore, control of this weed is important to manage the occurrence and impact of $C$. gloeosporioides in commercial crops. 
Fig. 2 Consensus tree based on the Maximum Likelihood method based on the Jukes-Cantor model illustrating the phylogenetic relationships between Colletotrichum gloeosporioides and selected species. The tree was built using concatenated sequences of the TUB2, CHS-1, ACT, GAPDH, and CAL sequences genes. Monilochaetes infuscans was used as outgroup

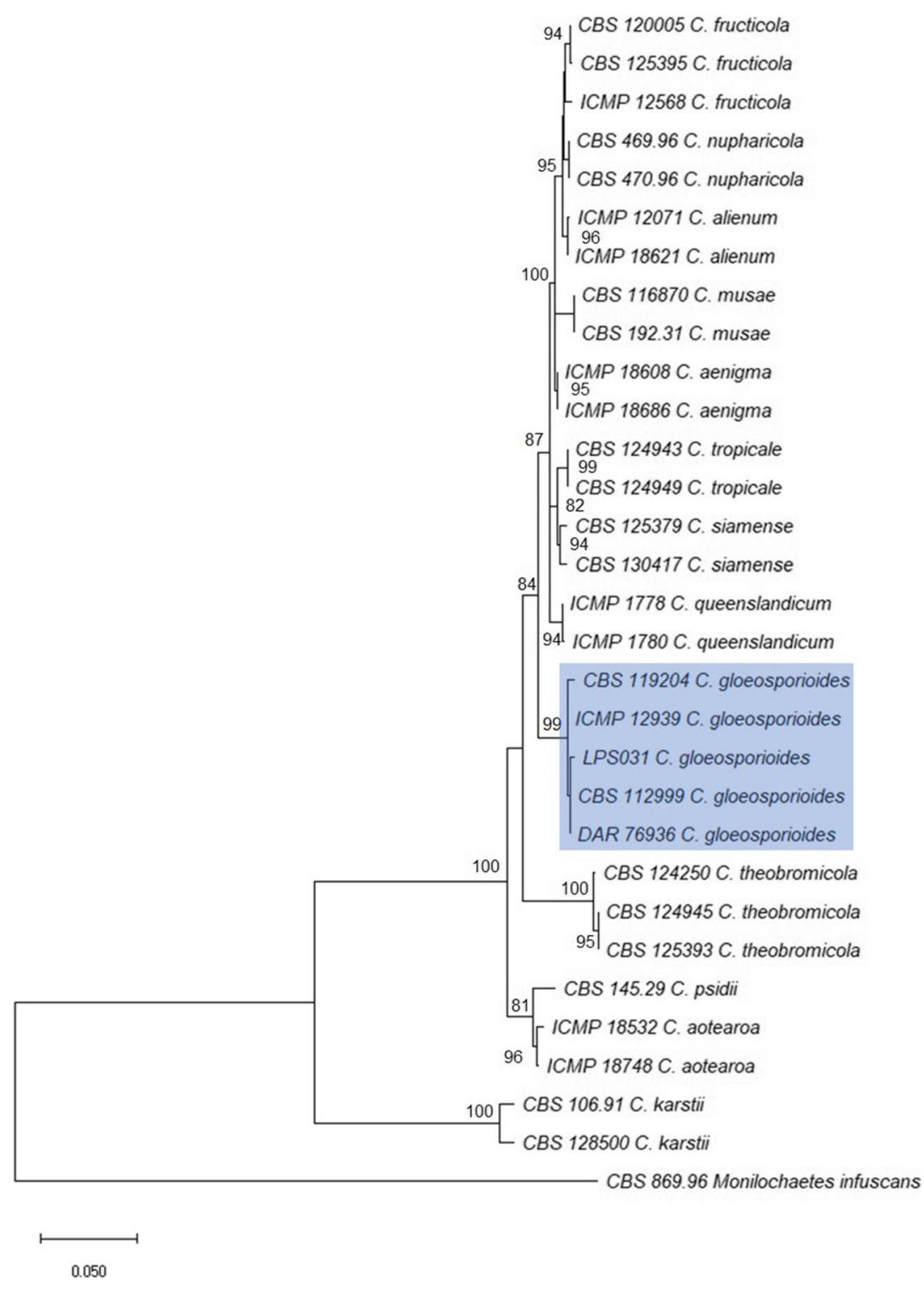

\section{References}

Agrios GN (2005) Plant pathology, 5th edn. Academic Press, New York ANDEF (2019) Colletotrichum gloeosporioides. Associação Nacional de Defesa Vegetal. http://www.defesavegetal.net/glomci . Accessed 6 August 2019

Bellé C, Kaspary TE, Schmitt J, Kuhn PR (2016) Meloidogyne ethiopica and Meloidogyne arenaria parasitizing Oxalis corniculata in Brazil. Australasian Plant Dis Notes 11:24-23. https://doi.org/10.1007/ s13314-016-0212-7

CABI (2019) Invasive species compendium. CAB International. https:// www.cabi.org/isc/datasheet/38154. Accessed 26 June 2019

Cannon PF, Damm U, Johnston PR, Weir BS (2012) Colletotrichum current status and future directions. Stud Mycol 73:181-213. https:// doi.org/10.3114/sim0014

Farr DF, Rossman AY (2019). Fungal Databases, Syst. Mycol. Microbiol. Lab., ARS, USDA. https://nt.ars-grin.gov/fungaldatabases/. Accessed 6 August 2019

Guerra FA, Brücher E, Rossi RL, Plazas MC, Guerra GD, Ducass DA (2016) First report of Oxalis conorrhiza as alternate host of Puccinia sorghi, causal agent of common rust of maize. Plant Dis 100:519
Hodi AM, Bese G, Hodi L, Palkovics L (2014) Role of Oxalis corniculate L. as plant virus reser-voir with special regard to tomato spotted wilt virus (TSWV-RB) strain occurrence in rock-wool cultivation in Hungary. Julius-Kühn-Archiv 443:239-243. https://doi.org/10. 5073/jka.2014.443.029

Jukes TH, Cantor CR (1969) Evolution of protein molecules. In: Munro HN (ed) Mammalian Protein Metabolism. Academic Press, New York, pp 21-132

Kumar S, Stecher G, Tamura K (2016) MEGA7: molecular evolutionary genetics analysis version 7.0 for bigger datasets. Mol Biol Evol 33: 1870-1874

Thompson JD, Gibson TJ, Plewniak F, Jeanmougin F, Higgins DG (1997) The Clustal_X windows interface: flexible strategies for multiple sequence alignment aided by quality analysis tools. Nucleic Acids Res 25:4876-4882. https://doi.org/10.1093/nar/25.24.4876

Weir BS, Johnston PR, Damm U (2012) The Colletotrichum gloeosporioides species complex. Stud Mycol 73:115-180. https:// doi.org/10.3114/sim0011 